\title{
ESTUDO DO EFEITO INIBITÓRIO DE ISOLADOS DE BACTÉRIAS \\ LÁTICAS PROVENIENTES DE GRAMÍNEAS, TOMATE, BETERRABA E FRUTAS CÍTRICAS SOBRE FUSARIOSE DO ABACAXI (ANANAS COMOSUS \\ (L.) MERRIL).)
}

\section{$\underline{\text { Débora de Jesus Barbosa }^{1} \text {; Elinalva Maciel Paulo }}{ }^{2}$; Hugo Neves Brandão ${ }^{3}$; Ilana Maciel Paulo Mamédio 4}

1. Bolsista PIBIC/FAPESB, Graduando em Ciências Biológicas, Universidade Estadual de Feira de Santana, e-mail: deborabarbosa.fs@hotmail.com

2. Orientador, Departamento de Biologia, Universidade Estadual de Feira de Santana, e-mail: elinalvamaciel@gmail.com

3. Participante do projeto, Hugo Neves Brandão, e-mail hugohnb@gmail.com

4. Co-orientadora, Departamento de Ciências Biológicas, Universidade Estadual de Feira de Santana, e-mail: ilana_mamedio@hotmail.com

PALAVRAS-CHAVE: Controle biológico, Fusariose, Bactérias láticas

\section{INTRODUÇÃO}

O abacaxi (Ananas comosus (L.) Merril) é uma monocotiledônea, da família Bromeliaceae, subfamília Bromeloideae. O Brasil é o segundo maior produtor mundial de abacaxi, perdendo apenas para a Tailândia. A fusariose do abacaxizeiro é a doença mais grave dessa cultura no Brasil, causando podridão dos tecidos afetados acompanhada por exsudação de substâncias gomosas (Matos; Cabral, 2005). Fusarium guttiforme é o agente etiológico da fusariose, que constitui séria ameaça à abacaxicultura. Uma das alternativas de controlar a proliferação do $F u$ sarium é através do controle biológico. As bactérias láticas apresentam grande potencial para inibição do crescimento fúngico, assim como quanto à detoxificação de micotoxinas. Essa atividade antimicrobiana pode estar associada à competição por nutrientes, à produção dos ácidos lático, orgânico e acético, além da produção de peróxido de hidrogênio, um importantíssimo agente antagônico (FRANCO, 2010). O uso de micro-organismoss antagonistas é uma alternativa para o controle biológico, sendo este o objetivo do presente trabalho frente à fusariose do abacaxizeiro . 


\section{METODOLOGIA}

\section{Micro-organismos:}

Os isolados de bactérias láticas devidamente caracterizadas foram adquiridas da bacterioteca do LAMASP. O isolado de Fusarium guttiforme foi adquirido da bacterioteca do Lamasp que foi proveniente de um projeto de mestrado em andamento realizado no referido laboratório.

\section{Ativação das bactérias láticas Checagem da pureza da cultura lática (PAULO, 2012)}

As culturas de bactérias ácido lácticas congeladas foram repicadas três vezes consecutivas em tubos contendo 2 mL de caldo MRS (De Man, Rogosa, Scharp, 1960), incubados por $48 \mathrm{~h}$ à $35^{\circ} \mathrm{C}$, para a sua ativação metabólica. As culturas foram checadas quanto a sua purificação, através da realização de análises preliminares de identificação de bactérias lácticas, que consiste na realização de teste de produção da catalase, da análise morfotintorial realizando a técnica de coloração de Gram e da produção de ácidos orgânicos, através da determinação do $\mathrm{pH}$ após proliferação no caldo $\mathrm{MRS}, \mathrm{pH}$ 6,5. A determinação do $\mathrm{pH}$ foi realizada no pHâmetro. O eletrodo do $\mathrm{pH}$ foi calibrado com solução tampão (Merck®) de pH 4,0 e 7,0.

\section{Avaliação da atividade antifúngica das bactérias láticas}

10 Isolados de bactérias láticas foram testados por meio do método de difusão em Agar proposto por Corsetti et al., (1998). Em uma placa de Petri previamente esterilizada foram dispostos $10 \mathrm{~mL}$ de BDA previamente inoculado com a suspensão de propágulos de Fusarium guttiforme a uma concentração de $10^{5}$ propágulos. $\mathrm{mL}^{-1}$, quantificados com o auxílio de Câmera de Neubauer e microscópio de luz. Após a solidificação do meio, as placas foram incubadas em estufa tipo B.O.D. por $22^{\circ} \mathrm{C}$ durante 24 horas. Após esse período foram dispostos sobre a superfície do Agar discos de papel de filtro $\mathrm{n}^{\circ} 1$ estéreis, apresentando $5 \mathrm{~mm}$ de diâmetro. Foram aplicados $100 \mu \mathrm{L}$ de suspensão bacteriana, após o líquido ser fixado pelos discos, as placas retornaram à B.O.D. por $22^{\circ} \mathrm{C}$ durante 10 dias. Também foi realizado o teste controle, onde os discos acrescentados na placa não contiam inoculante. As placas foram observadas, e os halos de inibição mensurados com auxílio de uma régua milimetrada. 
A suspensão de propágulos foi feita a multiplicação de Fusarium guttiforme em tubos contendo meio BDA (bisel longo) incubados a $22^{\circ} \mathrm{C}$ por 7 dias. $\mathrm{O}$ inóculo de propágulos foi preparado através de suspensão de conídios em solução salina a $0,85 \%$ : Tween 80 (9:1, v/v) agitando em Vortex por 5 minutos. Após agitação, o conteúdo líquido foi transferido para tubos de vidro estéreis. A determinação da concentração de propágulos foi realizada por contagem com auxílio de uma câmara de Neubauer e microscópio de luz, com um aumento óptico de 400 vezes.

A suspensão bacteriana foi preparada utilizando culturas bacterianas láticas previamente armazenadas sob refrigeração ou congeladas. Estas foram reativados e incubados a $30^{\circ} \mathrm{C}$ por 48 horas. O volume necessário de caldo MRS inoculado será transferido a um tubo contendo MRS estéril até que essa suspensão se ajuste ao tubo 10 da escala de Mac Farland, o que corresponde à uma concentração de 3,0 x $10^{9}$ UFC. $\mathrm{mL}^{-1}$. Também foi realizado o teste de Concentração Mínima Inibitória (MIC), no qual se utiliza uma microplaca de poliestireno com 96 poços, cada um com capacidade de $300 \mu \mathrm{L}$, acrescentando-se o Cloreto de Trifenil Tetrazólio (TTC) com 24h de incubação.

\section{RESULTADOS E DISCUSSÃO}

Foram utilizadas oito isolados de bactérias láticas provenientes de três vegetais: UR 205 e UR 23 da uva; LAC T34, LAC T5 e LAC T16 do tomate; ABX 9.1, ABX 7.1 e ABX 4.2 do abacaxi, Através do teste de difusão em disco, que fornece resultados qualitativos, observou-se que não houve inibição do agente causador da fusariose frente cepas bacterianas, apesar de ter ocorrido formação de halo em 24 horas. Os halos formados não indicaram inibição, visto que o disco contendo o agente antimicrobiano foi rapidamente invadido pelo patógeno. As médias dos halos de inibição das BAL frente ao patógeno variaram entre $10 \mathrm{~mm}$ e $15,8 \mathrm{~mm}$ conforme TABELA 1 . Contudo, a diferença de tamanho entre os halos foi insignificante, não podendo ser considerada como resultante de efeito antagônico.

Tabela 1. Médias do diâmetro $(\mathrm{mm})$ dos halos de inibição em $24 \mathrm{~h}$ de incubação do teste de inibição de diferentes isolados de bactérias láticas frente ao fungo Fusarium guttiforme.

\begin{tabular}{|c|c|c|c|c|c|c|c|c|c|c|}
\hline Tratamento & $\begin{array}{c}\text { UR } \\
205\end{array}$ & UR23 & $\begin{array}{c}\text { LAC } \\
\text { T 34 }\end{array}$ & $\begin{array}{c}\text { LAC } \\
\text { T 16 }\end{array}$ & $\begin{array}{c}\text { LAC } \\
\text { T 5 }\end{array}$ & $\begin{array}{c}\text { ABX } \\
9.1\end{array}$ & $\begin{array}{c}\text { ABX } \\
7.1\end{array}$ & $\begin{array}{c}\text { ABX } \\
4.2\end{array}$ & C+ & C- \\
\hline $\begin{array}{c}\text { Média dos } \\
\text { halos (mm) }\end{array}$ & 15,6 & 13,1 & 15,3 & 14 & 11,5 & 12 & 10 & 15,8 & 11,5 & 37,8 \\
\hline
\end{tabular}


No teste do MIC, com exceção dos testes controles, todos os poços da placa tiveram crescimento fúngico, exibindo coloração vermelha. Desta forma, tanto no MIC, como no teste de difusão em disco o efeito inibitório foi constatado apenas quando foi utilizado o fungicida nos tratamentos. Nogueira et al. (2014) descreve essa sensibilidade do fungo causador da fusariose do abacaxizeiro ao tratamento com controle químico.

\section{CONSIDERAÇÕES FINAIS}

Através das técnicas de difusão em disco e Concentração Mínima Inibitória (MIC), constatou-se a ausência de inibição fúngica utilizando-se isolados de bactérias láticas provenientes de diferentes vegetais. Sugere-se, portanto, a continuidade deste trabalho utilizando diferentes cepas provenientes de outros substratos vegetais de maneira a constatar o efeito inibitório das BAL contra o Fusarium guttiforme.

\section{REFERÊNCIAS}

CORSETTI, A. et al. Antimould activity of sourdough lactic acid bacteria: Identification of a mixture of organic acids produced by Lactobacillus sanfrancisco CB1. Applied Microbiology and Biotechnology, v.50, p253-256, 1998.

CRESTANI, M. et al. Das Américas para o Mundo origem, domesticação e dispersão do abacaxizeiro. Cienc. Rural [online]. 2010, vol.40, n.6, pp. 1473-1483.

DE MAN, J.C.; ROGOSA, M.; SHARPE, M.E. A medium for cultivation of lactobacilli. J. Appl. Bacteriol., 23,130-135, 1960.

FRANCO, T. S. Bactérias láticas no biocontrole Fusarium graminearum e na detoxificação de desonxinifalenol, 2010. 108 f. Dissertação ( Mestrado em Ciências de Alimentos)- Universidade Estadual de Londrina, 2010.

NOGUEIRA, R. et al. Fungicidas no controle de fusariose do abacaxi no estado de Tocantins, Brasil. Revista de Ciências Agrárias, v. 37, n. 4, p. 447-455, 2014. Disponível em: <http://Www.scielo.mec.pt/scielo.php?script=sci_arttext\&pid=S0871018X2014000400010> Acesso em: jul, 2017. 